\title{
Ileal pH and apparent absorption of magnesium in rats fed on diets containing either lactose or lactulose
}

\author{
BY ASTRID M. P. HEIJNEN ${ }^{1,2}$, ELIZABETH J. BRINK ${ }^{3}$, \\ ARNOLDINA G. LEMMENS ${ }^{1}$ AND ANTON C. BEYNEN ${ }^{1.2 *}$ \\ ${ }^{1}$ Department of Laboratory Animal Science, State University, PO Box 80.166 , \\ 3508 TD Utrecht, The Netherlands \\ ${ }^{2}$ Department of Human Nutrition, Agricultural University, PO Box 8129 , \\ 6700 EV Wageningen, The Netherlands \\ ${ }^{3}$ Department of Nutrition, Netherlands Institute for Dairy Science, PO Box 20, \\ 6710 BA Ede, The Netherlands
}

(Received 17 June 1992 - Accepted 4 January 1993)

\begin{abstract}
The hypothesis was tested that dietary lactose $v$. glucose stimulates $\mathrm{Mg}$ absorption in rats because lactose lowers $\mathrm{pH}$ of the ileal lumen, which improves $\mathrm{Mg}$ solubility which in turn enhances $\mathrm{Mg}$ availability for transport across the ileal epithelium. For comparison, the effects of lactulose were studied because it shares with lactose the characteristic of being poorly digestible. Replacement of glucose by lactose $(100 \mathrm{~g} / \mathrm{Kg})$ significantly stimulated apparent absorption of $\mathrm{Mg}$. Apart from $\mathrm{Mg}$ absorption, lactulose also significantly enhanced absorption of $\mathrm{Ca}$ and phosphate. Lactose $v$. glucose lowered the $\mathrm{pH}$ of the ileal lumen from 7.5 to 7.2 , whereas lactulose significantly reduced it to 7.0 . In in vitro incubations a decrease in $\mathrm{pH}$ within the range of fluctuation in vivo was found to cause an improved solubility of $\mathrm{Mg}$, and to a lesser extent also of $\mathrm{Ca}$ and phosphate. The smaller fall of ileal $\mathrm{pH}$ induced by feeding lactose instead of lactulose may explain why lactose improved $\mathrm{Mg}$ absorption only. For all individual rats combined there were negative relationships between ileal $\mathrm{pH}$ and apparent absorption of minerals, the relationship being strongest for $\mathrm{Mg}$. Neither lactose nor lactulose was found to raise ileal solubility of minerals, which could relate to the possibility that the time of sampling was not appropriate. It is suggested that lactose-induced stimulation of $\mathrm{Mg}$ absorption in rats is caused by a lowering of ileal $\mathrm{pH}$.
\end{abstract}

Dietary lactose: Lactulose: Magnesium: Rat

Dietary lactose $(\beta$-1,4-galactosyl-glucose) $v$. various other carbohydrates influences mineral absorption in rats. Lactose has been consistently shown to improve apparent $\mathrm{Mg}$ absorption (Andrieux \& Sacquet, 1983; Schaafsma et al. 1988; Greger et al. 1989; Behling \& Greger, 1990; Brink et al. 1991), whereas apparent Ca absorption was enhanced in some studies (Fournier et al. 1971; Leichter \& Tolensky, 1975; Armbrecht \& Wasserman, 1976; Favus \& Angeid-Backmann, 1984), but not in others (Greger et al. 1987; Sheikh et al. 1987; Recker et al. 1988; Behling \& Greger, 1990). Lactose was found to accelerate the appearance of label in blood when rats were administered lactose and radioactive phosphate together orally (Debiec \& Lorenc, 1988). However, in feeding trials no effect of lactose on apparent phosphate absorption was found (Schaafsma et al. 1988). The mechanism by which lactose stimulates $\mathrm{Mg}$ absorption is not known. Rats become lactase deficient after weaning (De Groot \& Hoogendoorn, 1957) and, thus, lactose is poorly digested. This may induce microbial fermentation of lactose in the ileum, as has been shown for arabinose which is also a poorly digestible carbohydrate (Schutte et al. 1992).

\footnotetext{
* For reprints.
} 
Fermentation of lactose may lower the $\mathrm{pH}$ in the ileal lumen. Insoluble $\mathrm{Ca}-\mathrm{Mg}-\mathrm{phosphate}$ complexes occur in the ileum (Brink et al. 1992), and a lowered $\mathrm{pH}$ should prevent the formation of these complexes and, thus, improve solubility of the mineral components (Greenwald et al. 1940). Only soluble minerals may cross the ileal epithelium (Bronner, 1987; Hardwick et al. 1991), which is the most prominent site in Mg absorption (Hardwick et al. 1991). Thus, it could be hypothesized that lactose lowers the $\mathrm{pH}$ in the ileal lumen, which enhances ileal solubility of $\mathrm{Mg}$ and, thus, stimulates its absorption. However, lactose may not have a major impact on ileal solubility of $\mathrm{Ca}$ and phosphate and consequently has no effect on $\mathrm{Ca}$ and phosphate absorption either. This hypothesis was tested in in vitro experiments and a feeding trial with weanling female rats. To see whether the hypothesis can be generalized, the effects of feeding another poorly digestible carbohydrate, lactulose ( $\beta$-1,4-galactosyl-fructose; Pomare et al. 1985) were studied as well.

\section{MATERIALS AND METHODS \\ Animals and housing}

We used female, outbred Wistar rats (Hsd/Cpb:WU; Harlan, Zeist, The Netherlands), aged about 3 weeks. The experimental protocol was approved by the Animal Experiment Committee of the Department of Laboratory Animal Science, Utrecht State University. On arrival the rats were fed ad lib. on a commercial, pelleted diet (RMH-B; Hope Farms, Woerden, The Netherlands) and tap water. They were housed in wire-topped polycarbonate cages $(375 \times 225 \times 150 \mathrm{~mm})$ with a layer of sawdust as bedding. At $4 \mathrm{~d}$ after arrival all rats were fed on the purified control diet (Table 1) and demineralized water ad lib. After another $8 \mathrm{~d}$ (day 0 of the experiment) the rats were divided into three groups of twelve animals each, so that group mean body weights were similar. As from day 0 the rats were housed individually in metabolic cages $\left(31400 \mathrm{~mm}^{2} \times 120 \mathrm{~mm}\right)$. The cages were placed in a room with controlled temperature $\left(20-22^{\circ}\right)$, lighting (light: $06.00-18.00$ hours) and relative humidity $(50-65 \%)$.

\section{Diets}

During the experimental period (days 0-21, 0-22 or 0-23) one group of rats remained on the control diet (Table 1). The other groups were fed on diets with $100 \mathrm{~g}$ lactose or lactulose $/ \mathrm{kg}$. These diets were formulated by adding the carbohydrates to the control diet at the expense of the glucose component. Analysis indicated that the carbohydrates contained negligible amounts $(<0.01 \mathrm{~g} / \mathrm{kg})$ of $\mathrm{Mg}$, Ca and phosphate.

As from day 0 the rats were transferred gradually to the test diets: one-fifth of the control diet was replaced daily by the test diets until the transfer was complete after $5 \mathrm{~d}$. The purified diets, which were in powdered form, were stored at $4^{\circ}$ until feeding. The rats had free access to food and demineralized water. Feed consumption and body weight were recorded at regular intervals. The experiment lasted $21-23 \mathrm{~d}$.

\section{Collection of samples}

From day 17 to day 19 faeces and urine of each rat were collected quantitatively. The cages and tubes for collection of faeces and urine were washed with a phosphate-free detergent (Briljant Rose Biosept; Rogier Bosman Chemie, Heijningen, The Netherlands) and rinsed thoroughly with $0 \cdot 1 \mathrm{~mol} \mathrm{HCl} / 1$ and demineralized water.

On day 21 , between 08.30 and 11.00 hours, four rats from each dietary group were anaesthetized by exposure to diethyl ether. Blood was obtained by orbital puncture and the rats immediately killed by cervical dislocation. The entire small intestine between stomach and caecum was removed. The contents in the distal third of the intestine (ileum) were collected in preweighed tubes by gently squeezing the intestine between finger and thumb. The ileal contents were immediately centrifuged $(10 \mathrm{~min}, 10000 \mathrm{~g})$, and the supernatant 
Table 1. Composition of the experimental diets

\begin{tabular}{|c|c|c|c|}
\hline & Control* & Lactose & Lactulose \\
\hline \multicolumn{4}{|l|}{ Ingredient $(\mathrm{g})$} \\
\hline Glucoset & $709 \cdot 4$ & $609 \cdot 4$ & $609 \cdot 4$ \\
\hline Lactosef & - & $100 \cdot 0$ & - \\
\hline Lactulose§ & - & - & $149 \cdot 9$ \\
\hline Constant components \| & $290 \cdot 6$ & $290 \cdot 6$ & $290 \cdot 6$ \\
\hline \multicolumn{4}{|l|}{ Chemical analysis } \\
\hline Dry matter $(\mathrm{g} / \mathrm{kg})$ & 941 & 941 & 893 \\
\hline $\mathrm{Ca}(\mathrm{mmol} / \mathrm{kg})$ & 112.5 & $115 \cdot 0$ & $107 \cdot 5$ \\
\hline $\mathrm{Mg}(\mathrm{mmol} / \mathrm{kg})$ & $16 \cdot 4$ & $16 \cdot 4$ & $16 \cdot 4$ \\
\hline Phosphate $(\mathrm{mmol} / \mathrm{kg})$ & $125 \cdot 8$ & $129 \cdot 0$ & $135 \cdot 4$ \\
\hline
\end{tabular}

* This diet also served as pre-experimental diet.

$\dagger$ Morsweet 01934; Cerestar, Haubourdin, France.

\$ Whey Products, Borculo, The Netherlands.

$\S$ Duphulac; Duphar BV, Amsterdam, The Netherlands; this lactulose preparation contained $333 \mathrm{~g}$ water $/ \mathrm{kg}$.

$\|$ The constant components consisted of (g): casein 151 , maize oil 25 , coconut fat 25 , cellulose $30, \mathrm{CaCO}_{3} 12 \cdot 4$, $\mathrm{MgCO}_{3} 1 \cdot 4, \mathrm{NaH}_{2} \mathrm{PO}_{4} \cdot 2 \mathrm{H}_{2} \mathrm{O} 15 \cdot 1, \mathrm{KCl} 1 \cdot 0, \mathrm{KHCO}_{3} 7 \cdot 7$, mineral premix 10 , vitamin premix 12 . The mineral premix consisted of (mg): $\mathrm{FeSO}_{4} \cdot 7 \mathrm{H}_{2} \mathrm{O} 174, \mathrm{MnO}_{2} 79, \mathrm{ZnSO}_{4} \cdot \mathrm{H}_{2} \mathrm{O} 33, \mathrm{NiSO}_{4} \cdot 6 \mathrm{H}_{2} \mathrm{O} 13$, NaF 2, KI 0.2, $\mathrm{CuSO}_{4} \cdot 5 \mathrm{H}_{2} \mathrm{O} 15 \cdot 7, \mathrm{Na}_{2} \mathrm{SeO}_{3} .5 \mathrm{H}_{2} \mathrm{O} 0 \cdot 3, \mathrm{CrCl}_{3} .6 \mathrm{H}_{2} \mathrm{O} 1 \cdot 5, \mathrm{SnCl}_{2} . \mathrm{H}_{2} \mathrm{O} 1 \cdot 9, \mathrm{NH}_{4} \mathrm{VO}_{3} 0 \cdot 2$, maize meal $9679 \cdot 2$. The vitamin premix consisted of $(\mathrm{mg})$ : thiamin 4 , riboflavin 3, niacinamide 20 , DL-calcium pantothenate $17 \cdot 8$, pyridoxine 6 , cyanocobalamin 50 , choline chloride 2000 , folic acid 1 , biotin 2 , menadione 0.05 , DL- $\alpha$-tocopheryl acetate 60 , retinyl acetate and retinyl palmitate 8 , cholecalciferol 2 , maize meal $9826 \cdot 15$.

fraction and pellet were separated. The weights of pellet and supernatant fraction were determined. The $\mathrm{pH}$ of the supernatant fraction was measured directly (Russell combination pH electrode, Type RS-53; Auchtermuchty, Fife, UK). Trichloroacetic acid (TCA) was added to the supernatant fraction to a final concentration of $54 \mathrm{~g} / 1$ and the TCA-soluble fraction obtained by centrifugation $(2 \mathrm{~min}, 10000 \mathrm{~g})$. Pellet and TCA-soluble fractions were analysed for minerals. Caecum (including its contents), kidney and liver were excised and weighed. On days 22 and 23 the entire procedure was repeated with the remaining rats.

\section{In vitro experiments}

To check whether the $\mathrm{pH}$ within the range of observed fluctuation in the ileal fluid affects mineral solubility, in vitro experiments were carried out. The unique advantage of such experiments is that the influence of $\mathrm{pH}$ as the only variable can be ascertained. The molar $\mathrm{Ca}$ :phosphate: $\mathrm{Mg}$ value in the incubations was chosen to be $6: 6: 1$, which is similar to that in the diet. Incubations had a final volume of $1 \mathrm{ml}$ and contained $(\mathrm{mmol} / 1)$ in distilled water either MOPS $50(\mathrm{pH}, 6 \cdot 4-7 \cdot 4)$ or HEPES $50(\mathrm{pH}, 7 \cdot 6-8 \cdot 2)$ and $\mathrm{MgCl}_{2} 3 \cdot 5, \mathrm{CaCl}_{2} 20$, $\mathrm{Na}_{2} \mathrm{HPO}_{4} 20$ and variable amounts of $\mathrm{NaCl}$ to maintain the ionic strength at $150 \mathrm{mmol} / 1$. The mixture $(0.9 \mathrm{ml})$ without $\mathrm{Na}_{2} \mathrm{HPO}_{4}$ was pre-incubated for $10 \mathrm{~min}$ at $37^{\circ}$ in a shaking water-bath. Then, $0.1 \mathrm{ml} \mathrm{Na} \mathrm{HPO}_{4}(200 \mathrm{mmol} / \mathrm{l})$ was added and the mixture further incubated for another $15 \mathrm{~min}$. The tubes were then centrifuged $(2 \mathrm{~min}, 10000 \mathrm{~g}$ ), supernatant fractions collected and the $\mathrm{pH}$ measured. After dilution of the supernatant fraction with TCA (final concentration $50 \mathrm{~g} / 1$ ), $\mathrm{Mg}, \mathrm{Ca}$ and phosphate were analysed.

\section{Chemical analyses}

$\mathrm{Mg}$ and $\mathrm{Ca}$ in samples of ileal contents, faeces, urine, diets and supernatant fractions of in vitro incubations were analysed as described elsewhere (Hoek et al. 1988; Mars et al. 1988). Phosphate was determined in ashed feed samples dissolved in $6 \mathrm{M}-\mathrm{HCl}$ with the use of a commercial test combination (Phosphate, MA-KIT 10 ROCHE; Roche Diagnostics, 
Table 2. Effects of dietary lactose and lactulose on growth performance, selected organ weights and excreta production in rats*

(Values are means with their standard errors for twelve rats per dietary group)

\begin{tabular}{|c|c|c|c|c|c|c|}
\hline \multirow[t]{2}{*}{ Diet... } & \multicolumn{2}{|c|}{ Control } & \multicolumn{2}{|c|}{ Lactose } & \multicolumn{2}{|c|}{ Lactulose } \\
\hline & Mean & SE & Mean & $\mathrm{SE}$ & Mean & SE \\
\hline \multicolumn{7}{|l|}{ Body wt } \\
\hline Initial $(\mathrm{g})$ & 94 & 2 & 94 & 2 & 94 & 2 \\
\hline Final (g) & $160^{\mathrm{b}}$ & 4 & $156^{a b}$ & 3 & $148^{\mathrm{a}}$ & 2 \\
\hline Feed intake $(\mathrm{g} / \mathrm{d})$ & $12 \cdot 6^{\mathrm{b}}$ & $0 \cdot 4$ & $12 \cdot 1^{\mathrm{ah}}$ & $0 \cdot 1$ & $11 \cdot 4^{\mathrm{a}}$ & 0.2 \\
\hline \multicolumn{7}{|c|}{ Relative organ wt (g/kg body $w \mathrm{t})$} \\
\hline Kidney & $3 \cdot 9$ & $0 \cdot 1$ & $3 \cdot 8$ & $0 \cdot 1$ & 3.6 & $0 \cdot 1$ \\
\hline Caecum & $8 \cdot 3^{\mathrm{u}}$ & 0.5 & $14 \cdot 4^{b}$ & $0 \cdot 9$ & $30 \cdot 9^{\mathrm{e}}$ & $1 \cdot 6$ \\
\hline Liver & $42 \cdot 9$ & $0 \cdot 8$ & $43 \cdot 1$ & $0 \cdot 8$ & $41 \cdot 2$ & 0.7 \\
\hline \multicolumn{7}{|l|}{ Faeces } \\
\hline Production $(\mathrm{g} / \mathrm{d})$ & $0 \cdot 9^{\mathrm{a}}$ & $0 \cdot 1$ & $1 \cdot 0^{\mathrm{ab}}$ & $0 \cdot 1$ & $1 \cdot 2^{b}$ & $0 \cdot 1$ \\
\hline Dry matter $(\mathrm{g} / \mathrm{kg})$ & $693^{\circ}$ & 10 & $600^{\mathrm{b}}$ & 16 & $534^{a}$ & 11 \\
\hline \multicolumn{7}{|l|}{ Urine } \\
\hline Production $(\mathrm{ml} / \mathrm{d})$ & $4 \cdot 1^{\mathrm{a}}$ & $0 \cdot 3$ & $3 \cdot 8^{a}$ & $0 \cdot 3$ & $5 \cdot 8^{b}$ & $0 \cdot 4$ \\
\hline
\end{tabular}

a.b." Group means with unlike superscript letters were significantly different (Tukey's test ; $P<0.05$ ).

* For details of diets and procedures, see Table 1 and pp. 748-749.

Basel, Switzerland) and a COBAS-BIO auto-analyser (Hoffmann-La Roche BV, Mijdrecht, The Netherlands). For complete recovery of phosphate from the ashed samples, analysis was performed at least 1 week after dissolution.

\section{Calculations}

The distribution of minerals between the solid and liquid phases of ileal contents was calculated. The pellet obtained after centrifugation of the ileal contents comprises the solid phase contaminated with liquid phase. Weight of the solid phase was obtained after freezedrying the pellet. Weight of the liquid phase was calculated as the sum of weight of the liquid phase in the pellet (=total pellet weight minus solid phase) and that of the supernatant fraction. The concentration of minerals in the supernatant fraction was assumed to be identical to that in the liquid phase. The amount of minerals in the solid phase was calculated as that in the total pellet minus that in the liquid phase of the pellet. Multiplying mineral concentration $(\mathrm{mmol} / \mathrm{l})$ in the supernatant fraction by the weight of the liquid phase gave the amount of minerals in the liquid phase. The relative amount of mineral in the liquid phase was computed as a percentage of the total amount in the ileal contents.

Apparent absorption of minerals was calculated as mineral intake minus faecal excretion and expressed as percentage of intake. Retention of minerals was calculated as mineral intake minus faecal plus urinary excretion and expressed as percentage of intake.

\section{Statistical analyses}

Differences between group means were evaluated with Tukey's test. The level of significance was preset at $P<0.05$.

\section{RESULTS}

Growth and organ weights

Final body weight and feed intake of rats fed on the lactulose diet were significantly lower than those of the control group (Table 2). Relative kidney and liver weights were similar 
Table 3. Effects of dietary lactose and lactulose on the balance of calcium and magnesium in rats*

(Values are means with their standard errors for twelve rats per dietary group)

\begin{tabular}{|c|c|c|c|c|c|c|}
\hline \multirow[t]{2}{*}{ Diet . } & \multicolumn{2}{|c|}{ Control } & \multicolumn{2}{|c|}{ Lactose } & \multicolumn{2}{|c|}{ Lactulose } \\
\hline & Mean & SE & Mean & SE & Mean & $\mathrm{SE}$ \\
\hline \multicolumn{7}{|l|}{$\mathrm{Ca}$} \\
\hline Intake $(\mu \mathrm{mol} / \mathrm{d})$ & 1418 & 61 & 1402 & 21 & 1330 & 27 \\
\hline $\begin{array}{l}\text { Faecal excretion } \\
(\mu \mathrm{mol} / \mathrm{d})\end{array}$ & $708^{b}$ & 55 & $587^{\mathrm{ab}}$ & 23 & $503^{\mathrm{a}}$ & 38 \\
\hline Absorption: $\mu \mathrm{mol} / \mathrm{d}$ & 708 & 46 & 815 & 35 & 826 & 44 \\
\hline$\%$ of intake & $50^{\mathrm{a}}$ & 3 & $58^{\mathrm{ab}}$ & 2 & $62^{\mathrm{b}}$ & 3 \\
\hline $\begin{array}{l}\text { Urinary excretion } \\
(\mu \mathrm{mol} / \mathrm{d})\end{array}$ & $10^{\mathrm{a}}$ & 1 & $10^{\mathrm{a}}$ & 2 & $30^{\mathrm{b}}$ & 3 \\
\hline Retention $(\mu \mathrm{mol} / \mathrm{d})$ & 699 & 46 & 804 & 35 & 796 & 43 \\
\hline \multicolumn{7}{|l|}{$\mathrm{Mg}$} \\
\hline Intake $(\mu \mathrm{mol} / \mathrm{d})$ & 198 & 8 & 189 & 2 & 189 & 3 \\
\hline $\begin{array}{l}\text { Faecal excretion } \\
(\mu \mathrm{mol} / \mathrm{d})\end{array}$ & $95^{\mathrm{c}}$ & 7 & $58^{\mathrm{b}}$ & 2 & $37^{\mathrm{a}}$ & 2 \\
\hline Absorption: $\mu \mathrm{mol} / \mathrm{d}$ & $103^{a}$ & 7 & $134^{\mathrm{b}}$ & 4 & $145^{\mathrm{b}}$ & 4 \\
\hline$\%$ of intake & $52^{\mathrm{a}}$ & 3 & $70^{\mathrm{b}}$ & 1 & $79^{c}$ & 1 \\
\hline $\begin{array}{l}\text { Urinary excretion } \\
(\mu \mathrm{mol} / \mathrm{d})\end{array}$ & 33 & 5 & 37 & 3 & 41 & 3 \\
\hline Retention $(\mu \mathrm{mol} / \mathrm{d})$ & $71^{\mathrm{a}}$ & 5 & $95^{\mathrm{h}}$ & 5 & $102^{\mathrm{b}}$ & 5 \\
\hline \multicolumn{7}{|l|}{ Phosphate } \\
\hline Intake $(\mu \mathrm{mol} / \mathrm{d})$ & 1584 & 69 & 1574 & 24 & 1675 & 33 \\
\hline $\begin{array}{l}\text { Faecal excretion } \\
(\mu \mathrm{mol} / \mathrm{d})\end{array}$ & 561 & 42 & 481 & 17 & 474 & 33 \\
\hline Absorption: $\mu \mathrm{mol} / \mathrm{d}$ & $1023^{a}$ & 48 & $1094^{\mathrm{ab}}$ & 34 & $1201^{b}$ & 43 \\
\hline$\%$ of intake & $65^{\mathrm{a}}$ & 2 & $69^{\mathrm{ab}}$ & 1 & $72^{\mathrm{b}}$ & 2 \\
\hline $\begin{array}{l}\text { Urinary excretion } \\
(\mu \mathrm{mol} / \mathrm{d})\end{array}$ & 452 & 48 & 448 & 17 & 355 & 14 \\
\hline Retention $(\mu \mathrm{mol} / \mathrm{d})$ & $568^{\mathrm{a}}$ & 45 & $645^{b}$ & 34 & $847^{\mathrm{c}}$ & 51 \\
\hline
\end{tabular}

a, b, c Group means with unlike superscript letters were significantly different (Tukey's test; $P<0.05$ ).

* For details of diets and procedures, see Table 1 and pp. 748-750.

for all groups. Weight of caecum with contents was significantly elevated in rats fed on lactose or lactulose. Lactulose produced a more than twofold higher caecum weight than did lactose.

\section{Excreta production}

Faeces production of rats fed on the lactulose diets was significantly higher than that of rats fed on the control diet containing glucose (Table 2). This was due to the elevated water content of faeces in the rats fed on lactulose. Lactose also produced an increment in the amount of water in faeces but this effect was less pronounced. Group mean urine production was highest in the lactulose group.

\section{Mineral balance}

Table 3 shows that intakes of minerals during the balance period (days 17-19) were similar in the dietary groups. Lactose significantly raised apparent $\mathrm{Mg}$ absorption, but did not affect that of phosphate. Lactose did not significantly affect urinary mineral excretion. Apparent absorption and retention of $\mathrm{Mg}$ and phosphate were significantly higher in the rats fed on lactulose than in those fed on glucose. 
Table 4. Effect of dietary lactose and lactulose on the distribution of calcium and magnesium between the liquid and solid phase in the ileal lumen in rats*

(Values are means with their standard errors for twelve rats per dietary group)

\begin{tabular}{|c|c|c|c|c|c|c|}
\hline \multirow[t]{2}{*}{ Diet... } & \multicolumn{2}{|c|}{ Control } & \multicolumn{2}{|c|}{ Lactose } & \multicolumn{2}{|c|}{ Lactulose } \\
\hline & Mean & $\mathrm{SE}$ & Mean & $\mathrm{SE}$ & Mean & $\mathrm{SE}$ \\
\hline Liquid phase: wt (g) & $0 \cdot 30^{2}$ & 0.02 & $0.36^{\mathrm{ab}}$ & 0.03 & $0 \cdot 42^{\mathrm{b}}$ & $0-03$ \\
\hline $\mathrm{pH}$ & $7 \cdot 5^{b}$ & $0 \cdot 1$ & $7 \cdot 2^{\mathrm{ab}}$ & $0 \cdot 1$ & $7 \cdot 0^{\mathrm{a}}$ & 0.1 \\
\hline Solid phase: wt (g) & $0-10$ & 0.01 & 0.09 & 0.01 & 0.10 & $0 \cdot 01$ \\
\hline \multicolumn{7}{|l|}{$\mathrm{Ca}$} \\
\hline $\begin{array}{l}\text { Amount in liquid phase } \\
(\mu \mathrm{mol})\end{array}$ & $3 \cdot 5^{\mathrm{a}}$ & $0 \cdot 3$ & $5 \cdot 8^{\mathrm{b}}$ & 0.6 & $6 \cdot 0^{b}$ & $0 \cdot 8$ \\
\hline $\begin{array}{l}\text { Amount in solid phase } \\
(\mu \mathrm{mol})\end{array}$ & 90 & 12 & 88 & 10 & 62 & 7 \\
\hline Percentage in liquid phase & $4 \cdot 0^{\mathrm{a}}$ & 0.5 & $6 \cdot 5^{\mathrm{ab}}$ & 0.7 & $9 \cdot 0^{\mathrm{b}}$ & 1.0 \\
\hline $\begin{array}{l}\text { Concentration in liquid } \\
\text { phase }(\mathrm{mmol} / \mathrm{l})\end{array}$ & 12 & 2 & 16 & 1 & 14 & 2 \\
\hline \multicolumn{7}{|l|}{$\mathrm{Mg}$} \\
\hline $\begin{array}{l}\text { Amount in liquid phase } \\
(\mu \mathrm{mol})\end{array}$ & $4 \cdot 5^{\mathrm{b}}$ & $0 \cdot 3$ & $4 \cdot 5^{b}$ & $0 \cdot 3$ & $2 \cdot 9^{\mathrm{a}}$ & $0 \cdot 3$ \\
\hline $\begin{array}{l}\text { Amount in solid phase } \\
(\mu \mathrm{mol})\end{array}$ & $9^{b}$ & 1 & $8^{\mathrm{b}}$ & 1 & $5^{\mathrm{a}}$ & 1 \\
\hline Percentage in liquid phase & 35 & 3 & 38 & 3 & 40 & 4 \\
\hline $\begin{array}{l}\text { Concentration in liquid } \\
\text { phase }(\mathrm{mmol} / \mathrm{l})\end{array}$ & $16^{\mathrm{b}}$ & 1 & $13^{\mathrm{b}}$ & 1 & $7^{\mathrm{a}}$ & 1 \\
\hline \multicolumn{7}{|l|}{ Phosphate } \\
\hline $\begin{array}{l}\text { Amount in liquid phase } \\
(\mu \mathrm{mol})\end{array}$ & $1 \cdot 3$ & $0 \cdot 2$ & $1 \cdot 3$ & $0 \cdot 2$ & 1.9 & $0 \cdot 2$ \\
\hline $\begin{array}{l}\text { Amount in solid phase } \\
(\mu \mathrm{mol})\end{array}$ & 67 & 8 & 69 & 7 & 55 & 6 \\
\hline Percentage in liquid phase & 1.7 & $0 \cdot 3$ & 1.5 & $0 \cdot 2$ & $3 \cdot 8$ & 1.8 \\
\hline $\begin{array}{l}\text { Concentration in liquid } \\
\text { phase }(\mathrm{mmol} / \mathrm{l})\end{array}$ & 3.9 & 0.5 & $2 \cdot 6$ & $0 \cdot 3$ & $4 \cdot 5$ & $0 \cdot 7$ \\
\hline
\end{tabular}

a. b.c Group means with unlike superscript letters were significantly different (Tukey's test; $P<0.05$ ).

* For details of diets and procedures, see Table 1 and pp. 748-750.

Apparent absorption of $\mathrm{Ca}$ was not significantly affected by lactose, whereas $\mathrm{Ca}$ absorption was significantly increased in rats fed on lactulose. In the rats fed on the lactulose diet, urinary $\mathrm{Ca}$ excretion was significantly elevated.

\section{Minerals in the ileal lumen}

Rats fed on lactulose had significantly more liquid phase in their ileal lumen than rats fed on the control diet (Table 4). Lactose and lactulose produced a lower group mean $\mathrm{pH}$ of the liquid phase than did glucose, but the lowering was statistically significant only for lactulose. The amount of solid phase in the ileal lumen was similar for all dietary groups.

$\mathrm{Ca}$ concentration in the liquid phase did not differ significantly between the dietary groups. However, lactose and lactulose raised the absolute amount of $\mathrm{Ca}$ in the liquid phase. The amount of $\mathrm{Ca}$ in the solid phase was similar for the three groups. The percentage of total $\mathrm{Ca}$ in the liquid phase in the ileal lumen was significantly elevated in the lactulose group and tended to be elevated in the rats fed on lactose when compared with the control group.

Group mean amounts of $\mathrm{Mg}$ in the liquid and solid phases in rats fed on the lactulose 


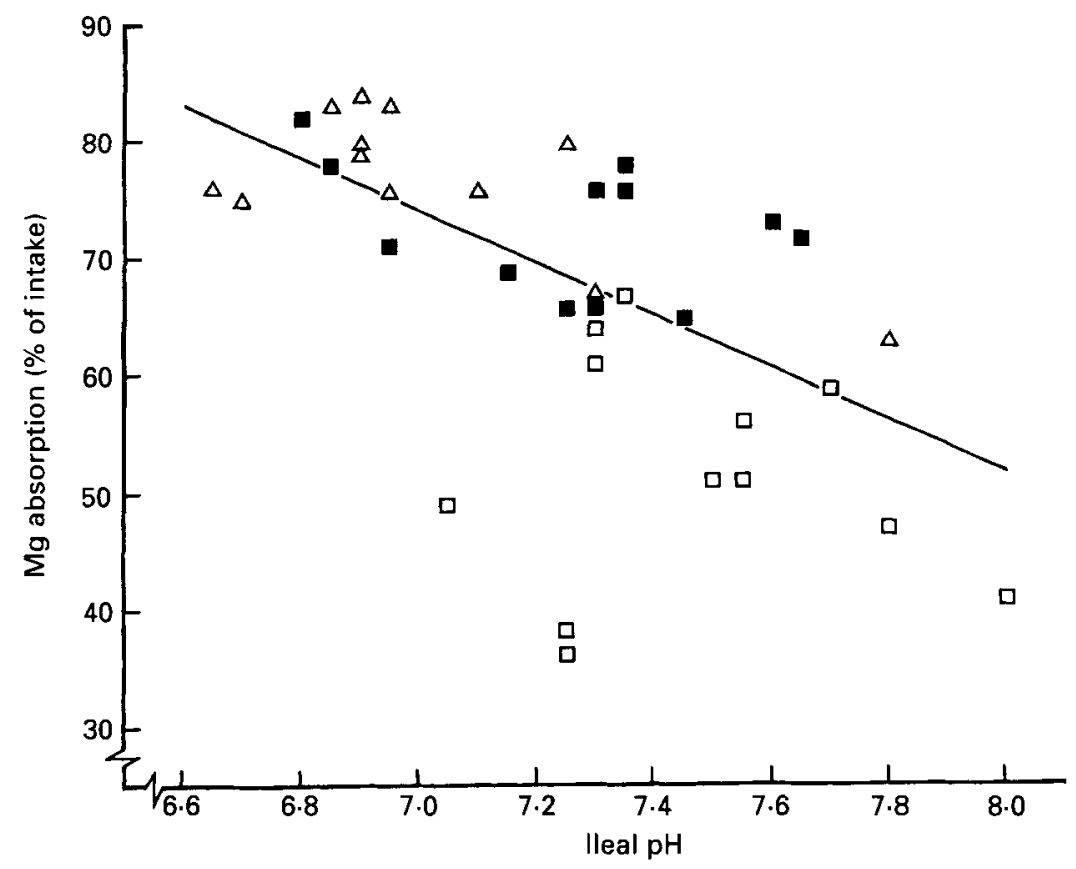

Fig. 1. Relationship between $\mathrm{pH}$ in the ileal lumen and percentage apparent magnesium absorption in rats fed on the experimental diets $(y=-22 x+229, r-0.69, n 36)$. ( $\square)$, Control; $(\square)$, lactose; $\triangle \triangle$ ), lactulose. For details of diets and procedures, see Table 1 and pp. 748-750.

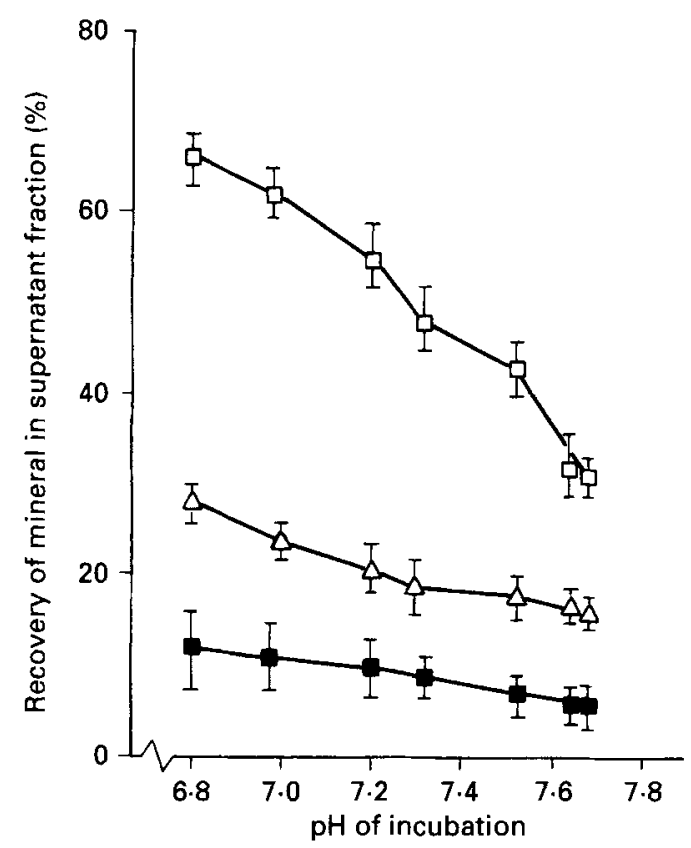

Fig. 2. Magnesium $(\square)$, calcium $(\square)$ and phosphate $(\triangle)$ in supernatant fractions of in vitro incubations of solutions at varying $\mathrm{pH}$. Recovery in the supernatant fraction is expressed as a percentage of the total amount of mineral in the incubation. Values are means and standard deviations represented by vertical bars for six determinations. For details of procedures, see pp. $748-749$. 
diet were lower than those in rats fed on the other diets. The proportion of soluble $\mathrm{Mg}$ did not differ significantly between the dietary groups.

Concentrations of phosphate in the liquid phase and the amount of phosphate in the solid phase were not significantly affected by the experimental diets. The absolute amount and percentage of phosphate in the liquid phase tended to be elevated in the lactulose group.

\section{Ileal $\mathrm{pH}$ and mineral absorption}

There was a negative relationship between the $\mathrm{pH}$ in the ileal lumen and percentage apparent $\mathrm{Mg}$ absorption (Fig. 1). Similar relationships, although less strong, were calculated for $\mathrm{Ca}(r-0 \cdot 40, n 36)$ and phosphate $(r-0 \cdot 44, n 36)$.

\section{In vitro solubility of minerals}

Within the $\mathrm{pH}$ range of 6.8 to $7 \cdot 7$, the $\mathrm{pH}$ and the percentages of $\mathrm{Mg}, \mathrm{Ca}$ and phosphate in the supernatant fraction of the incubations were negatively associated (Fig. 2). The increase in solubility with decreasing $\mathrm{pH}$ was most pronounced for $\mathrm{Mg}$.

\section{DISCUSSION}

As would be expected (Beynen, 1989; Henskens et al. 1991), the feeding of either lactose or lactulose produced markedly elevated caecum weights. This substantiates the low digestibility of these carbohydrates (Pomare et al. 1985; Andrieux et al. 1989) and their suitability as substrates for intestinal bacterial fermentation. Lactulose caused an enlargement of intestinal bulk as evidenced by the elevated weight of the ileal liquid phase, and raised faecal weight due to enrichment with moisture. Lactose tended to have similar effects, but those of lactulose were much more pronounced. Lactulose also stimulated urine production, which may partly be caused by the higher water content of the lactulose diet.

The present study shows that dietary lactose $v$. glucose significantly enhanced the apparent absorption of $\mathrm{Mg}$, which corroborates other reports (Andrieux \& Sacquet, 1983; Schaafsma et al. 1988; Greger et al. 1989; Behling \& Greger 1990; Brink et al. 1991). Lactose $v$. glucose caused an increment in group mean $\mathrm{Ca}$ absorption, but this effect failed to reach statistical significance. Similar results have been published by others (Fournier et al. 1971; Leichter \& Tolensky, 1975; Armbrecht \& Wasserman, 1976; Favus \& AngeidBackmann, 1984). Lactose in the diet did not significantly affect apparent phosphate absorption, which agrees with other work (Schaafsma et al. 1988). In the present study marked effects of lactulose on mineral absorption emerged. Lactulose $v$. glucose significantly stimulated the apparent absorption of $\mathrm{Mg}, \mathrm{Ca}$ and phosphate. Another poorly digestible carbohydrate which is structurally related to lactulose, lactitol ( $\beta$-D-galactopyranosyl-1,4-D-sorbitol), has also been shown to enhance Ca absorption (Ammann et al. 1988).

The major objective of the present study was to find out why lactose stimulates $\mathrm{Mg}$ absorption. This can be extended by the question why lactulose enhances the absorption of $\mathrm{Mg}, \mathrm{Ca}$ and phosphate. We had hypothesized that lactose lowers the $\mathrm{pH}$ in the ileal lumen, thereby improving the solubility of $\mathrm{Mg}$ which in turn elevates the amount of $\mathrm{Mg}$ that can cross the ileal epithelium. A similar cascade of events could explain lactuloseinduced stimulation of mineral absorption. From the outset a number of limitations of the experimental design used should be discussed. Ileal $\mathrm{pH}$ and soluble minerals in ileal digesta were determined at one point of time, whereas apparent mineral absorption was a measure integrated over $3 \mathrm{~d}$. Time-dependent fluctuations in ileal variables could weaken the relationship, if any, between ileal variables and apparent absorption of minerals. Thus, a lack of correlation between ileal $\mathrm{pH}$ or ileal soluble $\mathrm{Mg}$ and $\mathrm{Mg}$ absorption cannot 
conclusively disprove our hypothesis. Furthermore, the rats had been fed on an ad lib. basis and no attempt was made to standardize the amount and timing of food intake. Thus, any group differences in eating behaviour would hinder the demonstration of a possible relationship between ileal $\mathrm{pH}$ or ileal soluble $\mathrm{Mg}$ and apparent $\mathrm{Mg}$ absorption.

Lactose $v$. glucose tended to lower the $\mathrm{pH}$ of the intestinal digesta. With the use of in vitro incubations we demonstrated that a lowering of $\mathrm{pH}$ from 7.5 to $7 \cdot 2$, which was found in vivo when dietary glucose was replaced by lactose, caused an improved solubility of $\mathrm{Mg}$. Similar effects, although much less pronounced, were seen for $\mathrm{Ca}$ and phosphate. However, dietary lactose did not raise the proportion and concentration of $\mathrm{Mg}, \mathrm{Ca}$ and phosphate in the liquid phase of ileal digesta. Dietary lactulose significantly lowered the ileal $\mathrm{pH}$ from 7.5 to 7.0. In keeping with the effects seen in vitro, dietary lactulose $v$. glucose caused a significant increment in the proportion of $\mathrm{Ca}$ in the ileal liquid phase but it did not affect $\mathrm{Ca}$ concentration. Lactulose also raised group mean proportions of soluble $\mathrm{Mg}$ and phosphate. Due to the large within-group variation these effects did not reach statistical significance. Thus, there is no solid evidence that lactulose raised ileal solubility of $\mathrm{Mg}, \mathrm{Ca}$ and phosphate.

For all individual rats combined, negative relationships between $\mathrm{pH}$ in the ileal lumen and apparent absorption of $\mathrm{Mg}, \mathrm{Ca}$ and $\mathrm{P}$ could be demonstrated. As would be expected on the basis of in vitro observations (Fig. 2), the relationship was strongest for $\mathrm{Mg}$ (Fig. 1). The observed negative relationship between ileal $\mathrm{pH}$ and apparent $\mathrm{Mg}$ absorption is consistent with the first part of our hypothesis. However, the second part of our hypothesis, that is the existence of a positive relationship between ileal soluble $\mathrm{Mg}$ and $\mathrm{Mg}$ absorption, is not supported by the present study. As mentioned previously it is possible that the experimental design used prevented the demonstration of a relationship between ileal soluble $\mathrm{Mg}$ and apparent $\mathrm{Mg}$ absorption.

The concentration of minerals in the liquid phase of the ileal contents may determine mineral absorption rather than the proportions of minerals in the liquid phase. Within this concept, lactulose should elevate the concentration of minerals in the liquid phase. However, as mentioned previously, this was not seen. As to $\mathrm{Mg}$, the concentration in the liquid phase was even significantly lowered after feeding lactulose. This may relate to differences in timing of food intake or intestinal transit time between rats fed on either glucose or lactulose. This is supported by the observation that the intestine of rats fed on the lactulose diet tended to contain less minerals. If non-absorbable markers for the solid and liquid phases of digesta had been added to the diets it would have been possible to express ileal minerals relative to the markers. This would have facilitated interpretation of the results. Unfortunately we did not use non-absorbable markers.

In the present study we focussed on the ileum as predominant site in $\mathrm{Mg}$ absorption. Thus, any diet effects on Mg solubility in digesta from other sites of the gastrointestinal tract remain unknown. Mg (Hardwick et al. 1991), Ca (Petith \& Schedl, 1976; Beynen et al. 1990) and phosphate (Beynen et al. 1990) can be absorbed in the caecum and/or colon. Given the marked influence of lactose and lactulose on caecum weight it is likely that these disaccharides alter the milieu of the caecum and/or colon. Whether this influences overall mineral absorption is not known.

In conclusion, under the experimental conditions used the stimulatory effect of lactose on $\mathrm{Mg}$ absorption was not associated with increased solubility of $\mathrm{Mg}$ in the ileal lumen. However, the observed negative relationship between $\mathrm{pH}$ in the ileal lumen and intestinal $\mathrm{Mg}$ absorption indicates that the decrease in ileal $\mathrm{pH}$ after lactose feeding is responsible for the improved $\mathrm{Mg}$ absorption. 


\section{REFERENCES}

Ammann, P., Rizzoli, R. \& Fleisch, H. (1988). Influence of the disaccharide lactitol on intestinal absorption and body retention of calcium in rats. Journal of Nutrition 118, 793-795.

Andrieux, C., Gadelle, D., Leprince, C. \& Sacquet, E. (1989). Effects of some poorly digestible carbohydrates on bile acid bacterial transformations in the rat. British Journal of Nutrition 62, 103-119.

Andrieux, C. \& Sacquet, E. (1983). Effects of microflora and lactose on the absorption of calcium, phosphorus and magnesium in the hindgut of the rat. Réproduction, Nutrition Développement 23, 258-271.

Armbrecht, H. J. \& Wasserman, R. H. (1976). Enhancement of $\mathrm{Ca}^{++}$uptake by lactose in the rat small intestine. Journal of Nutrition 106, 1265-1271.

Behling, A. R. \& Greger, J. L. (1990). Importance of lactose in yoghurt for mineral utilization. Journal of Agriculture and Food Chemistry 38, 200-204.

Beynen, A. C. (1989). Increased concentration of liver cholesterol in rats fed lactulose. Die Nahrung 33, 89-90. Beynen, A. C., West, C. E., Spaaij, C. J. K., Huisman, J., Van Leeuwen, P., Schutte, J. B. \& Hackeng, W. H. L. (1990). Cholesterol metabolism, digestion rates and postprandial changes in serum of swine fed purified diets containing either casein or soybean protein. Journal of Nutrition 120, 422-430.

Brink, E. J., Beynen, A. C., Dekker, P. R., Van Beresteijn, E. C. H. \& Van der Meer, R. (1992). Interaction of calcium and phosphate decreases ileal magnesium solubility and apparent magnesium absorption in rats. Journal of Nutrition 122, 580-586.

Brink, E. J., Dekker, P. R., Van Beresteijn, E. C. H. \& Beynen, A. C. (1991). Inhibitory effect of dietary soybean protein vs. casein on magnesium absorption in rats. Journal of Nutrition 121, 1374-1381.

Bronner, F. (1987). Intestinal calcium absorption, mechanisms and applications. Journal of Nutrition 117 , $1347-1352$.

Debiec, H. \& Lorenc, R. (1988). Influence of lactose on phosphate metabolism in rats. British Journal of Nutrition 59, 87-92.

De Groot, A. P. \& Hoogendoorn, P. (1957). The detrimental effect of lactose. II. Quantitative lactase determinations in various mammals. Netherlands Milk and Dairy Journal 11, 290-303.

Favus, M. J. \& Angeid-Backmann, E. (1984). Effects of lactose on calcium absorption and secretion by rat ileum. American Journal of Physiology 246, G281-G285.

Fournier, P., Dupuis, Y.\& Fournier, A. (1971). Effect of lactose on the absorption of alkaline earth metals and intestinal lactase activity. Israel Journal of Medical Sciences 7, 389-391.

Greenwald, I., Redish, J. \& Kibrick, A. C. (1940). The dissociation of calcium and magnesium phosphates. Journal of Biological Chemistry 135, 65-76.

Greger, J. L., Gutkowski, C. M. \& Khazen, R. R. (1989). Interactions of lactose with calcium, magnesium and zinc in rats. Journal of Nutrition 119, 1691-1697.

Greger, J. L., Krzykowski, C. E., Khazen, R. R. \& Krashoc, C. (1987). Mineral utilization by rats fed commercially available calcium supplements or milk. Journal of Nutrition 117, 717-724.

Hardwick, L. L., Jones, M. R., Brautbar, N.\& Lee, D. B. N. (1991). Magnesium absorption: mechanisms and the influence of vitamin D, calcium and phosphate. Journal of Nutrition 121, 13-23.

Henskens, Y. M. C., Ritskes-Hoitinga, J., Mathot, J. N. J. J., Van Camp, I. \& Beynen, A. C. (1991). The influence of dietary lactose on phosphorus-induced nephrocalcinosis in female rats. International Journal for Vitamin and Nutrition Research 61, 77-86.

Hoek, A. C., Lemmens, A. G., Mullink, J. W. M. A. \& Beynen, A. C. (1988). Influence of dietary calcium: phosphorus ratio on mineral excretion and nephrocalcinosis in female rats. Journal of Nutrition 118, 1210-1216.

Leichter, J. \& Tolensky, A. F. (1975). Effect of dietary lactose on the absorption of protein, fat and calcium in the postweanling rat. American Journal of Clinical Nutrition 28, 238-241.

Mars, Y. W. H. M., Lemmens, A. G. \& Beynen, A. C. (1988). Dietary phosphorus and nephrocalcinosis in female rats. Nutrition Reports International 38, 249-258.

Petith, M. M. \& Schedl, H. P. (1976). Intestinal adaptation to dietary calcium restriction: in vivo cecal and colonic calcium transport in the rat. Gastroenterology 71, 1039-1042.

Pomare, E. W., Branch, W. J. \& Cummings, J. H. (1985). Carbohydrate fermentation in the human colon and its relation to acetate concentrations in venous blood. Journal of Clinical Investigation 75, 1448-1454.

Recker, R. R., Bammi, A., Barger-Lux, J. \& Heaney, R. (1988). Calcium absorbability from milk products, an imitation milk and calcium carbonate. American Journal of Clinical Nutrition 47, 93-95.

Schaafsma, G., Dekker, P. R. \& De Waard, H. (1988). Nutritional aspects of yoghurt. 2. Bioavailability of essential minerals and trace elements. Netherlands Milk and Dairy Journal 42, 135-146.

Schutte, J. B., De Jong, J., Van Weerden, E. J. \& Tamminga, S. (1992). Nutritional implications of L-arabinose in pigs. British Journal of Nutrition 68, 195-207.

Sheikh, M. S., Santa Ana, C. A., Nicar, M. J., Schiller, L. R. \& Fordtran, J. S. (1987). Gastrointestinai absorption of calcium salts. New England Journal of Medicine 317, 532-536. 